\title{
PERLINDUNGAN HUKUM BAGI PT TERHADAP PENGGUNAAN ASET PT UNTUK KEPENTINGAN PRIBADI OLEH PEMEGANG SAHAM
}

\author{
Nuzula Syafrial Ardy \\ Fakultas Hukum, Universitas Airlangga \\ e-mail: nuzula.ardi@gmail.com
}

\begin{abstract}
ABSTRAK
Tanggung jawab pemegang saham Perseroan Terbatas adalah terbatas sebesar saham yang dimilikinya, hal ini berdasarkan redaksi Pasal 3 ayat (1) Undang-Undang Nomor 40 Tahun 2007 tentang Perseroan Terbatas (UUPT). Namun dalam praktik banyak pemegang saham yang menyalahgunakan bentuk badan hukum Perseroan Terbatas untuk kepentingan pribadi, berdasarkan hal tersebut penulisan ini dimaksudkan untuk menganalisis sejauh mana pertanggungjawaban pemegang saham dalam memanfaatkan aset Perseroan Terbatas untuk kepentingan pribadi, dan upaya hukum apa yang dapat dilakukan untuk menyelamatkan aset Perseroan Terbatas dari gangguan pemegang saham. Penelitian ini merupakan penelitian normatif dan berdasarkan pendekatan perundang-undangan, pendekatan konseptual, dan pendekatan kasus. Hasil yang didapatkan dari penelitian ini adalah Perseroan Terbatas atau pihak yang berwenang yang mewakili Perseroan Terbatas tersebut dapat menggugat pemegang saham berdasarkan prosedur yang diatur UUPT
\end{abstract}

Kata Kunci: Perseroan Terbatas; Aset; Perlindungan Hukum

\begin{abstract}
The responsibility of the shareholders of a Limited Liability Company is limited to the shares they have, this is based on the editorial of Article 3 paragraph (1) of Law Number 40 of 2007 concerning Companies (UUPT). But in the practice of many shareholders who abuse the form of a Limited Liability Company legal entity for personal interest, based on this matter the purpose of this is to analyze the extent of shareholders' responsibility in utilizing Limited Liability Company assets for personal interests, and what legal actions can be taken to save Limited Liability Company assets from shareholder disruption. This research is a normative research and based on the legislative approach, conceptual approach, and case approach. The results obtained from this study are Limited Liability Company or authorized parties representing the Limited Liability Company can sue the shareholders based on the procedures regulated by the Company Law.
\end{abstract}

Keywords: Company; Company's Assets; Legal Protection

\section{PENDAHULUAN}

Perseroan Terbatas (selanjutnya disingkat PT) sebagai badan usaha dirasa mempunyai kelebihan tersendiri jika dibandingkan dengan badan usaha lainnya, salah satu alasannya bentuk PT merupakan badan hukum mandiri. Filosofis pemilihan badan hukum sebagai badan usaha bahwa dengan kematian pendiri, harta kekayaan badan hukum tersebut diharapkan masih mendapat manfaat bagi orang lain. ${ }^{1}$ Berdasarkan Pasal 1 angka 1 Undang-Undang Nomor 40 Tahun 2007 tentang Perseroan Terbatas (selanjutnya disebut UUPT). Secara teknis Organ PT terdiri dari Direksi, Komisaris, Rapat Umum

${ }^{1}$ Azizah. (2016). Hukum Perseroan Terbatas. Malang: Setara Press, h. 18, sebagaimana dikutip dari Nindyo Pramono. 
Pemegang Saham (selanjutnya disebut RUPS) RUPS merupakan organ yang penting, melalui RUPS pemegang saham berhak memperoleh segala keterangan yang berkaitan dengan kepentingan PT dari Direksi dan Komisaris guna melindungi kepentingannya, Pemegang saham merupakan salah satu komponen yang penting dalam PT, baik sebagai unsur kepemilikan maupun unsur pemodalan. ${ }^{2}$

Pemilik Modal sebagai pemegang saham memiliki kontrol terhadap terakhir terhadap pengelolaan dananya oleh Direksi dan hal tersebut dilakukan melalui RUPS. ${ }^{3}$ Kontrol yang dimiliki pemegang saham tersebut terhadap pengelolaan perusahaan dapat menyeret pemegang saham untuk masuk bertanggung jawab jika terjadi kerugian PT, pemegang saham dapat dimintai pertanggungjawaban berdasarkan kesalahannya pada Pasal 3 ayat (2) huruf b UUPT. PT pada asasnya memiliki ciri khusus mengenai pengumpulan modal dan pertanggungjawaban terbatas serta kemandirian dalam hukum yang dimilikinya, PT memiliki kedudukan dalam hukum "persona standi in juction" yang artinya PT diberikan kedudukan yang mandiri oleh hukum yang terlepas dari orang yang ada di dalam PT tesebut. ${ }^{4}$ Dengan karakteristik PT yang merupakan subjek hukum secara mandiri tersebut banyak dimanfaatkan oleh pihak-pihak yang tidak bertanggung jawab melakukan pemanfaatan kekayaan PT tidak sesuai dengan tujuan pribadi, dan menimbulkan kerugian.

Berbagai cara dapat dilakukan oleh pemegang saham atau pendiri menggunakan topeng PT sebagai badan hukum dan memanfaatkan kekayaan PT untuk keperluan pribadi. Dari hal tersebut doktrin piercing the corporate viel dapat menyeret Direksi, Komisaris maupun Pemegang Saham untuk bertanggung jawab lebih atas kerugian PT terhadap kesalahan yang dilakukan oleh organ PT. Kesalahankesalahan yang dilakukan oleh pemegang saham dapat merugikan pihak ketiga di luar PT, sebagai contoh asas PT merupakan badan hukum persona standi in juction maka hanya dapat menggugat PT saja, namun tanggung jawab PT tersebut dapat

${ }^{2}$ Bonifasius Aji Kuswiratmo. (2016). Keuntungan \& Resiko Menjadi Direktur, Komisaris dan Pemegang Saham. Cetakan Pertama. Jakarta: Visimedia, h. 92.

3 ibid., h. 95.

${ }^{4}$ Rudhi Prasetya. (2014). Teori dan Praktik Perseroan Terbatas. Jakarta: Sinar Grafika, h. 5. diperluas berdasarkan doktrin hukum piercing the corporate viel untuk menggugat atau untuk meminta pertanggungjawaban pada organ perseroan yang berada di balik PT.

Bentuk-bentuk kesalahan pemegang saham memanfaatkan aset PT berdasarkan redaksi Pasal 3 ayat (2) huruf b UUPT sebagai latar belakang penulisan ini yaitu sebagai berikut:

1. Pemanfaatan aset PT secara langsung.

2. Pemanfaatan aset PT secara tidak langsung:

a. Melalui Forum RUPS Pembagian Deviden Interim (Putusan Pengadilan Negeri Surabaya Nomor 83/Pdt.G/2016/PN.Sby).

b. Melalui Rangkap Jabatan Sebagai Direksi (Putusan Pengadilan Negeri Denpasar Nomor 1013/Pib.B/2013/PN.Dps).

\section{PERUMUSAN MASALAH}

Upaya hukum yang dapat dilakukan untuk mengembalikan aset PT terhadap pemanfaatan aset PT oleh pemegang saham untuk kepentingan pribadi.

\section{METODE PENELITIAN}

Tipe penelitian dalam penulisan ini adalah penelitian yaitu penulisan yang menjelaskan sebuah penjelasan yang sistematik mengenai aturan-aturan hukum yang mengatur sebab kategori hukum tertentu, menganalisis hubungan antar peraturan hukum, menjelaskan bidang-bidang kesulitan dan memungkinkan memprediksi perkembangan ke depan. ${ }^{5}$ Penulisan ini menggunakan 3 (dua) metode pendekatan yaitu Pendekatan Perundang-undangan (Statute Approach), Pendekatan Konseptual (Conseptual Approach), dan Pendekatan Kasus (Case Approach) pendekatan masalah yang bertumpu pada peraturan perundang-undangan yang berlaku di Indonesia yang berkaitan, khususnya UUPT.

\section{PEMBAHASAN}

Sebelum membahas mengenai penyalahgunaan aset PT oleh pemegang saham, perlu diketahui pemegang saham juga dibebani oleh kewajiban, setelah kewajiban tersebut terpenuhi barulah pemegang saham tersebut memiliki, Kewajiban pemegang saham timbul karena berkaitan dengan prinsip kemandirian perseroan yaitu pihak yang

\footnotetext{
5 Peter Mahmud Marzuki. (2009). Penelitian Hukum. Cetakan ke-5. Jakarta: Kencana Premada Media Group, h. 32.
} 
ingin masuk ke dalam suatu perseroan yaitu pihak yang ingin masuk ke dalam suatu perseroan dengan memasukkan bagiannya dalam bentuk modal, secara otomatis terikat pada akibat-akibat hukum yang timbul sehubungan dengan hal tersebut. ${ }^{6}$

Berikut kewajiban normatif pemegang saham yang diatur oleh UUPT:

1) Pemegang saham dibebani kewajiban yaitu memenuhi atau menyetor sejumlah uang yang dimiliki berdasarkan Pasal 33 ayat (1) UUPT yaitu dengan menyetorkan dan menempatkan minimal 25\% (dua puluh lima persen) dari modal dasar dan bertanggung jawab atas kerugian PT sebatas saham yang dimilikinya;

2) Kewajiban untuk menyelenggarakan RUPS sebagai bentuk menjalankan kegiatan usaha perseroan yaitu sekurang-kurangnya 1 (satu) tahun sekali atau yang disebut RUPS tahunan. ${ }^{7}$

Berikut hak-hak pemegang saham secara normatif berdasarkan UUPT:

1) Hak mengajukan gugatan ke Pengadilan Negeri tehadap PT akibat dirugikan karena tindakan PT dianggap tidak adil dan tanpa alasan yang wajar sebagai akibat keputusan RUPS, Direksi dan/ atau Dewan Komisaris (Pasal 61 ayat (1) UUPT);

2) Hak mengajukan gugatan kepada Pengadilan Negeri akibat kelalaian Direksi dan/atau Dewan Komisaris mengakibatkan kerugian pada PT (Pasal 95 ayat (6) jo Pasal 114 ayat (6) UUPT);

3) Hak meminta PT agar sahamnya dibeli dengan harga yang wajar akibat yang bersangkutan tidak menyetujui tindakan sebagaimana dimaksud Pasal 62 ayat (1) UUPT sebagai berikut: Setiap pemegang saham berhak meminta kepada Perseroan agar sahamnya dibeli dengan harga yang wajar apabila yang bersangkutan tidak menyetujui tindakan Perseroan yang merugikan pemegang saham atau Perseroan, berupa:

a. perubahan anggaran dasar;

b. pengalihan atau penjaminan kekayaan Perseroan yang mempunyai nilai lebih dari 50\% (lima puluh persen) kekayaan bersih Perseroan; atau

c. Penggabungan, Peleburan, Pengambilalihan, atau Pemisahan.

\footnotetext{
${ }^{6}$ Bonafasius Aji Kuswiratmo, op.cit., h. 98.

${ }^{7}$ ibid., h. 99.
}

4) Hak meminta Direksi untuk menyelenggarakan RUPS (Pasal 79 ayat (2) huruf a UUPT);

5) Hak mengajukan permohonan kepada ketua Pengadilan Negeri untuk melakukan pemanggilan sendiri RUPS Rahunan atau RUPS Lainnya (Pasal 80 ayat (1) UUPT);

6) Hak untuk mendapatkan salinan daftar pemegang saham, risalah, dan pembukuan kepada Direksi (Pasal 50 ayat (4) UUPT);

7) Hak untuk menghadiri dan memberikan suara dalam RUPS (Pasal 52 ayat 1 huruf (a) UUPT);

8) Hak mengajukan permohonan kepada Ketua Pengadilan Negeri untuk mengadakan pemeriksaan pada PT, jika terdapat perbuatan melawan hukum yang yang merugikan pemegang saham (Pasal 138 ayat (3) huruf a UUPT);

9) Hak mengajukan permohonan kepada Ketua Pengadilan Negeri untuk membubarkan PT (Pasal 146 ayat (1) UUPT);

10) Hak untuk mendapatkan prioritas penawaran atas pemindahan hak atas saham (Pasal 157 ayat (1) huruf a UUPT);

11) Hak atas pembayaran deviden atau sisa kekayaan hasil likuidasi (Pasal 52 ayat (1) huruf b).

Sebelum membahas mengenai bentuk kesalahan dari pemegang saham tersebut berikut akan diuraikan hak-hak dari pemegang saham dan berbagai dari hak tersebut dapat disalahgunakan sebagai bentuk pemanfaatan aset PT untuk kepentingan pribadi berikut berdasarkan ketentuan Pasal 52 ayat (1) UUPT yaitu sebagai berikut: a) Menghadiri dan mengeluarkan suara dalam RUPS; b) Menerima pembayaran deviden dan sisa kekayaan likuidasi; c) Menjalankan hak lainnya berdasarkan undangundang. Pada Pasal 52 UUPT tersebut kepemilikan saham sebagai benda bergerak memberikan "hak kebendaan" (vermogensrecht, property right) kepada pemiliknya untuk dapat dipertahankan terhadap semua orang atau droit de suite. ${ }^{8}$ Deviden merupakan hak dari pemegang saham yang kerapkali disalahgunakan sebagai pemanfaatan aset PT oleh pemegang saham melalui Forum RUPS.

\section{Contoh Pemanfaatan Aset PT Secara Langsung}

Berdasarkan ketentuan Pasal 3 ayat (2) huruf b UUPT membagi bentuk pemanfaatan aset PT oleh

\footnotetext{
${ }^{8}$ M. Yahya Harahap. (2015). Hukum Perseroan Terbatas Cetakan Kelima. Jakarta: Sinar Grafika, h. 274.
} 
pemegang saham secara langsung dan tidak langsung, bentuk pemanfaatan aset PT secara langsung dapat dicontohkan dengan pemegang saham menggunakan uang perusahaan tanpa melalui jabatan sebagai Direksi, maupun melalui forum RUPS. Dalam praktik pengambilan uang PT oleh pemegang saham tanpa melalui jabatan sebagai Direksi sulit dilakukan, karena hanya Direksi yang berwenang atas kegiatan operasional PT (Pasal 92 ayat (1) UUPT), untuk bentuk usaha PT yang merupakan badan hukum dengan tanggung jawab terbatas (Pasal 3 ayat (1) UUPT), pemegang saham atau pemilik modal tidak dapat melakukan pengambilan uang perusahaan, dalam praktik bisnis ekonomi disebut prive yaitu pengambilan modal oleh pemilik modal untuk kepentingan pribadi seperti pada badan usaha lainnya, karena PT merupakan subyek hukum yang mandiri modal yang telah disetorkan pada pendirian PT bukanlah milik pemegang saham atau pemilik modal, melainkan merupakan kekayaan atau aset PT, maka pengambilan uang PT untuk keperluan pribadi oleh pemilik modal dapat dikategorikan sebagai pelanggaran hukum. ${ }^{9}$

\section{Pemanfaatan Aset PT Secara Tidak Langsung}

Melalui forum RUPS, pemegang saham mayoritas memiliki pengendalian yang besar atas hak suaranya yang dapat dimanfaatkan untuk merugikan PT yang dilakukan melalui forum RUPS pembagian deviden interim. Mengenai pengertian deviden interim (Interim Dividend) menurut Pasal 75 ayat (1) UUPT yaitu deviden yang dibagikan sebelum tahun tutup buku perseroan, deviden interim tersebut boleh dibagikan jika jumlah kekayaan bersih perseroan tidak menjadi lebih kecil dari jumlah modal yang ditempatkan dan disetor ditambah cadangan wajib (Pasal 75 ayat (2) UUPT). Deviden interim tersebut merupakan bagian laba atau keuntungan perseroan yang bersifat sementara, belum merupakan deviden final yang ditetapkan berdasarkan keputusan RUPS. ${ }^{10}$

Deviden adalah pendistribusian laba kepada pemegang saham secara prorate, pada prinsipnya dibayarkan dalam bentuk uang namun juga dapat dibayarkan dalam bentuk script atau surat saham

9 R. Soemita dkk. (1980). Dasar-Dasar Akutansi I. Bandung: Tarsito, h. 59.

${ }^{10}$ M. Yahya Harahap, op.cit., h. 293. sementara maupun produk atau property perusahaan. ${ }^{11}$ Deviden merupakan salah satu hak yang dimiliki oleh pemegang saham, namun untuk membagi deviden tersebut tentunya wajib mematuhi ketentuan Pasal 70 ayat (1) UUPT yang mengharuskan PT wajib menyisihkan jumlah tertentu dari laba bersih untuk cadangan dan penyisihan dilakukan pada setiap tahun buku. Penjelasan Pasal 70 ayat (1) UUPT memberikan definisi laba bersih adalah keuntungan tahun berjalan setelah dikurangi pajak.

Dalam UUPT memberikan kewenangan pada pemegang saham melalui RUPS untuk memutuskan dan menentukan penggunaan laba bersih perseroan merupakan kewenangan yang tidak dimiliki oleh direksi atau komisaris (unauthorized), termasuk penentuan besarnya jumlah laba bersih, termasuk penyisihan besarnya cadangan wajib dan cadangan lainnya. ${ }^{12}$ Mengenai pembagian deviden interim penjelasan Pasal 75 UUPT memberikan contoh berikut: Dividen interim yang telah dibagikan sebesar Rp1.000,00 (seribu rupiah) per saham.

Perseroan menderita kerugian dan tidak mempunyai saldo laba positif sehingga tidak ada dividen yang dibagikan. Oleh karena itu, yang harus dikembalikan adalah Rp 1.000,00 (seribu rupiah) per saham. Seandainya Perseroan menderita kerugian, tetapi Perseroan mempunyai laba ditahan (retained earning) dan saldo laba positif hingga, misalnya RUPS menetapkan dividen sebesar Rp 200,00 (dua ratus rupiah) per saham. Oleh karena, itu saham yang harus dikembalikan adalah Rp 1.000,00 (seribu rupiah) dikurangi $\mathrm{Rp}$ 200,00 (dua ratus rupiah) berarti Rp 800,00 (delapan ratus rupiah).

Pembagian deviden interim tersebut merupakan tanggung jawab Direksi dan Dewan komisaris jika ternyata setelah pembagian deviden interim perseroan menderita kerugian dan pemegang saham tersebut tidak dapat mengembalikan deviden interim yang telah dibagikan (Pasal 72 ayat (6) UUPT).

Berdasarkan kasus Putusan Pengadilan Negeri Surabaya Nomor: 83/Pdt.G/2016/PN.Sby, SM selaku Direksi dan Pemegang Saham Mayoritas PT SJA melakukan pemanfaatan aset PT SJA untuk kepentingan pribadi melalui forum RUPS pembagian deviden interim yang mengakibatkan penurunan laba positif pada PT tahun buku 2014, tindakan SM dalam

\footnotetext{
11 ibid., h. 291.

12 ibid., h. 290.
} 
kapasitanya sebagai Direksi sekaligus pemegang saham mayoritas menyetujui atas pembagian tersebut tanpa memperdulikan akibat bagi kerugian pada kekayaan PT SJA karena saldo laba bersih perseroan menjadi negatif yang artinya PT SJA mengalami kerugian, majelis hakim menjatukan putusan mengembalikan deviden interim tersebut yang telah dibagikan, membatalkan RUPS mengenai pembagian deviden. Berdasarkan UUPT Pasal 72 ayat (2) mengatur mengenai pembagian deviden interim melalui RUPS yaitu dengan menetapkan jumlah penyisihan laba bersih untuk cadangan perseroan (Pasal 70 ayat (1) UUPT), kewenangan penetapan penggunaan laba bersih untuk deviden hanya dimiliki oleh pemegang saham melalui forum RUPS.

Berdasarkan penjelasan Pasal 71 ayat (1) UUPT mengatur mengenai mekanisme RUPS penggunaan laba bersih perseroan bahwa Keputusan RUPS pada ayat ini harus memperhatikan kepentingan Perseroan dan kewajaran. Berdasarkan keputusan RUPS tersebut dapat ditetapkan sebagian atau seluruh laba bersih digunakan untuk pembagian dividen kepada pemegang saham, cadangan, dan/atau pembagian lain seperti tansiem (tantieme) untuk anggota Direksi dan Dewan Komisaris, serta bonus untuk karyawan. Pemberian tansiem dan bonus yang dikaitkan dengan kinerja Perseroan telah dianggarkan dan diperhitungkan sebagai biaya.

Pemegang saham memiliki hak untuk penetapan laba bersih perseroan dalam RUPS (Pasal 70 ayat (1) UUPT) terkait penetapan penggunaan laba perseroan untuk membagi deviden interim perseroan sebagai pengambilan uang PT. Sementara pembagian deviden interim merupakan kewenangan Direksi berdasarkan keputusan Dewan Komisaris (Pasal 72 ayat (4) UUPT) untuk menetapkan pembagian deviden interim, Berdasarkan rumusan penjelasan Pasal 71 ayat (1) UUPT RUPS dalam hal pengunaan laba bersih haruslah memperhatikan kepentingan perseroan mengenai penggunaan laba bersih yaitu untuk cadangan perseroan, atau pembagian lain seperti tansiem (tantieme) untuk anggota Direksi dan Dewan Komisaris, serta bonus untuk karyawan. Pada putusan Pengadilan Negeri Surabaya 83/Pdt.G/2016/ PN.Sby bahwa SM selaku pemegang saham mayoritas melalui forum RUPS telah menetapkan penggunaan laba bersih perseroan untuk pembagian deviden interim, serta menetapkan pembagian deviden interim berdasarkan kapasitasnya sebagai Direksi. Tahun tutup buku 2014, namun perlu diperhatikan bahwa deviden interim untuk pemegang saham hanya boleh dibagikan ketika saldo laba perseroan telah mencapai positif pada akhir tahun tutup buku sesuai Pasal 72 ayat (2) UUPT.

Bahwa untuk pembagian deviden interim haruslah memperhatikan jumlah kekayaan bersih perseroan dan jumlah modal yang ditempatkan dan disetor oleh pemegang saham (Pasal 72 ayat (2) UUPT), disamping itu pembagian deviden interim juga tidak boleh menganggu atau menyebabkan perseroan tidak dapat memenuhi kewajibannya pada kreditor atau kegitan usaha perseroan (Pasal 72 ayat (3) UUPT). Perseroan hanya boleh membagikan keuntungan sebagai deviden apabila perseroan mempunyai "saldo laba positif" yang artinya seluruh laba bersih setelah dikurangi akumulasi kerugian tahun buku sebelumnya, dengan demikian hanya kelebihan keuntungan yang dapat dibagikan kepada pemegang saham dalam bentuk deviden. ${ }^{13}$ Terhadap pembagian deviden interim tersebut pemegang saham untuk mengembalikan deviden yang telah dibagikan jika ada kerugian PT SJA, pemegang saham telah melakukan tindakan itikad buruk menurut Pasal 3 ayat (2) huruf b UUPT yaitu dengan mengesampingkan kriteria jumlah cadangan perseroan dan kekayan bersih PT (Pasal 71 ayat (3) UUPT) serta memaksakan untuk pembagian deviden tahun buku 2014 yang dapat dikategorikan memanfaatkan kekayaan PT untuk kepentingan pribadi melalui forum RUPS.

\section{Pemanfaatan Aset PT Melalui Rangkap Jabatan Sebagai Direksi}

Sebagai contoh berikutnya pemanfataan PT secara tidak langsung yang dilakukan pemegang saham dengan merangkap jabatan sebagai Direksi yaitu dengan pencampuradukan kepentingan PT dengan kepentingan pribadi.

Pada dasarnya pemegang saham PT hanya bertanggung jawab secara terbatas berdasarkan Pasal 3 ayat (1) UUPT, terhadap pemegang saham yang menjabat sebagai anggota direksi secara otomatis merangkap tanggung jawab Direksi terhadap pengurusan PT sebagaimana dimaksud Pasal 97 ayat (1) UUPT yang menyatakan bahwa Direksi

\footnotetext{
13 ibid., h. 293.
} 
bertanggung jawab atas pengurusan Perseroan. Direksi berwenang melakukan pengurusan terhadap kekayaan PT, kekayaan tersebut merupakan benda perusahaan yang dapat dialihkan menurut hukum.

Terhadap pemegang saham yang merangkap jabatan sebagai Direksi berpotensial melakukan pencampuradukan kekayaan pribadi pemegang saham dengan kekayaan PT (Penjelasan Pasal 3 ayat (2) huruf b UUPT), bentuk pencampuran kekayaan PT pada kasus penulisan ini berdasarkan pada kasus Putusan Pengadilan Negeri Denpasar Nomor 1013/ Pib.B/2013/PN.Dps bahwa ADE selaku Direksi dan pemegang saham $50 \%$ (lima puluh persen) dari PT Cylax telah memanfaatkan aset PT melalui jabatannya selaku Direksi dengan menjual aset PT berupa HGB No. 254/Desa Pecatu An. PT Cylax International tanpa persetujuan dari RUPS, serta menggunakan hasil penjualan aset untuk keperluan pribadi dengan mentransfer hasil penjualan aset tersebut pada rekening pribadi direksi bahwa akibat dari perbuatan tersebut PT Cylax mengalami kerugian. Berikut contoh pencampuradukan kepentingan urusan PT dan urusan pribadi: a) Dana perusahaan dipergunakan untuk urusan pribadi; $b$ ) Aset milik PT diatasnamakan pribadi; c) Pembayaran perseroan dengan cek pribadi tanpa justifikasi yang jelas. ${ }^{14}$

Berdasarkan doktrin tersebut pemegang saham yang melakukan perbuatan pencampuradukan kekayaan PT dengan kekayaan pribadi (Pasal 3 ayat (2) huruf b UUPT), maka semua perikatan dengan pihak ketiga menjadi tanggung jawab pribadi pemegang saham yang bersangkutan, artinya terhadap pemenuhan kewajiban atas perikatan dengan pihak ketiga dapat dimintakan kepada pemegang saham. ${ }^{15}$

\section{Pertanggungjawaban Pribadi Pemegang Saham atas Pemanfaatan Aset PT}

Doktrin piercing the corporate viel atau menyingkap tabir perseroan diartikan bahwa sebagaian dari suatu proses untuk membebani tanggung jawab ke pundak orang lain atau perusahaan lain, atas tindakan hukum yang dilakukan suatu

\footnotetext{
${ }^{14}$ Munir Fuady. (2014). Doktrin-Doktrin Modern Dalam Corporate Law dan Eksistensinya dalam Hukum Indonesia. Cetakan ke III. Jakarta: Citra Aditya Bakti, h. 20.

15 Adrian Sutendi, op.cit., hlm. 161 sebagaimana dikutip dari Sutan Remy Sjahnedi. (2001). Jurnal Hukum Bisnis. Vol. 14, h. 109.
}

perusahaan pelaku (badan hukum) tanpa melihat kepada fakta bahwa perbuatan itu sebenarnya dilakukan oleh pelaku perseroan tersebut. ${ }^{16}$

Kasus yang memungkinkan terjadinya atau timbulnya kegiatan perseroan yang dapat mengakibatkan berlakunya doktrin piercing the corporate viel antara lain: a) Adanya kepentingan yang bertentangan (internal conflict) antara Direksi dan/atau Komisaris terhadap Perseroan; b) Direksi dan/atau Komisaris yang mengambilalih kesempatan yang sebenarnya milik perseroan untuk kepentingan pribadi atau usaha pribadi (business opportunity). Berdasarkan doktrin tersebut pemegang saham yang melakukan perbuatan pencampuradukan kekayaan PT dengan kekayaan pribadi (Pasal 3 ayat (2) huruf b UUPT), maka semua perikatan dengan pihak ketiga menjadi tanggung jawab pribadi pemegang saham yang bersangkutan, artinya terhadap pemenuhan kewajiban atas perikatan dengan pihak ketiga dapat dimintakan kepada pemegang saham. ${ }^{17}$

Teori piercing the corporate viel tersebut menitikberatkan pada kehendak untuk mempersonifikasikan badan hukum seolah-olah seperti manusia, teori-teori tersebut pada intinya memberikan landasan teoritis dan filasafati kepada kepada orang-orang yang berada di balik suatu badan hukum yaitu Direksi, Komisaris, dan Pemegang Saham agar mereka tidak melanggar prinsip-prinsip keadilan dalam mengelola perseroan termasuk kepada stakeholder yaitu pihak yang berhubungan dengan perseroan. ${ }^{18}$ Pada Pasal 3 ayat (2) huruf b UUPT tidak memberikan memberikan gambaran konkrit mengenai pemanfaatan aset PT, terdapat indikator bahwa pemegang saham dapat dimintai pertanggungjawaban secara pribadi yaitu: a) Terdapat penipuan terhadap kreditor; b) Kapital Tipis (thin capatilazion) yaitu perseroan kekurangan modal; c) Perampokan yaitu mentransfer aset PT kepada pemegang saham; d) Mengakali peraturan perundangan-undangan, misalnya PT dilarang

16 Munir Fuady. (1999). Hukum Perusahaan dalam Paradigma Hukum Bisnis. Bandung: Citra Aditya Bakti, h. 64-66.

${ }^{17}$ Adrian Sutedi, op.cit., h. 161 sebagaimana dikutip dari Sutan Remy Sjahnedi. (2001). Jurnal Hukum Bisnis. Vol. 14, h. 109.

${ }^{18}$ Try Widiono. (2013). "Perkembangan dan Teori Hukum dan Doktrin Hukum Piercing The Corporate Viel dalam UUPT dan Realitanya Secara Prospektif Kedepannya". Lex Jurnalica. Volume 10, h. 36. 
melakukan usaha dalam bidang retail di suatu, namun untuk menyimpangi peraturan tersebut seluruh asetnya dimiliki perseroan tersebut; e) Menghindari kewajiban dari pihak ketiga (envoiding an existing obligation). ${ }^{19}$

Dari indikator tersebut pemegang saham yang memanfaatkan aset PT baik secara langsung maupun tidak langsung yang dicontohkan melalui forum RUPS maupun yang merangkap jabatan sebagai Direksi telah melakukan perampokan aset PT pada butir 3 (tiga) di atas sebagai perbuatan melanggar hukum.

\section{Upaya Hukum Terhadap Penggunaan Aset PT Secara Langsung Upaya Hukum oleh Direksi}

Penggunaan aset PT secara langsung oleh pemegang saham dicontohkan dengan pengambilan uang perusahaan, pengambilan uang tersebut tidaklah dapat dilakukan jika pemegang saham tidak merangkap jabatan selaku Direksi, maka Direksi selaku pemegang kekuasaan operasional perusahaan hendaknya dapat mencegah atau melarang pemegang saham menggunakan aset PT untuk kepentingan pribadi, yaitu Direksi bertindak untuk atas nama PT (Pasal 92 ayat (1) UUPT), dengan cara menggugat secara perdata sebagai perbuatan melanggar hukum atau melaporkan secara pidana atas tindakan pemegang saham yang memanfaatkan aset PT.

\section{Upaya Hukum oleh Dewan Komisaris}

Dewan Komisaris tidak dapat melakukan upaya hukum secara langsung terkait pemanfaatan PT oleh Pemegang Saham, karena memiliki fungsi sebagai organ pengawasan atas kegiatan pengurusan PT (Pasal 108 ayat (1) UUPT). Jika Direksi membiarkan atau tidak melakukan upaya pencegahan atau tindakan terhadap pemanfaatan aset PT oleh pemegang saham, maka Dewan Komisaris PT selaku organ PT yang memiliki fungsi pengawasan dan memberikan saran pada Direksi (Pasal 1 angka 6 Jo Pasal 108 ayat (1) UUPT) dengan memberikan teguran pada Direksi untuk melakukan tindakan hukum menyelamatkan aset PT dari gangguan pemegang saham, jika Direksi terus mengabaikan dan tidak melakukan

\footnotetext{
${ }^{19}$ Kurniawan. (2014). "Tanggung Jawab Pemegang Saham Perseroan Terbatas Menurut Hukum Positif'. Jurnal Mimbar Hukum. Volume 26, h. 79.
}

upaya hukum terhadap penyelamatan aset PT maka Komisaris dapat melakukan upaya pemberhentian sementara anggota Direksi dengan alasan pembiaran pemanfaatan aset PT (Pasal 106 ayat (2) UUPT).

\section{Upaya Hukum oleh Pemegang Saham yang lain}

Pemegang saham lain tidak dapat secara langsung melakukan upaya hukum menggugat atas pemanfaatan aset PT, jika Direksi melakukan pembiaran atas hal tersebut, maka pemegang saham dapat menggugat Direksi bertindak mewakili PT (Pasal 95 ayat (6) UUPT) atau yang dikenal dengan gugatan derivatif, yaitu salah seorang pemegang saham atau lebih diberikan hak bertindak untuk kepentingan atas nama PT, yang mewakili 1/10 (satu persepuluh) bagian dengan dari jumlah seluruh saham dengan hak suara sah. ${ }^{20}$ Gugatan tersebut ditujukan kepada Direksi karena telah mengakibatkan kerugian pada PT, karena tidak melakukan upaya hukum terhadap pemanfaatan aset $\mathrm{PT}$ oleh pemegang saham untuk keperluan pribadi.

\section{Upaya Hukum terhadap Penggunaan Aset PT Melalui Forum RUPS Pembagian Deviden Interim}

Berdasarkan kasus Putusan Pengadilan Negeri Surabaya Nomor: 83/Pdt.G/2016/PN.Sby, SM selaku Direksi dan Pemegang Saham Mayoritas PT SJA telah memanfaatkan aset PT memalui pembagian deviden interim yang mengakibatkan PT SJA mngalami kerugian. Untuk penetapan pembagian deviden interim merupakan kewengan Direksi dan Dewan Komisaris (Pasal 72 ayat (4) UUPT) atas permintaan dari RUPS.

Komisaris tidak berwenang untuk menggugat Direksi dan/atau pemegang saham pada Pengadilan jika tidak dapat mengembalikan deviden yang telah dibagikan, Dewan Komisaris hanya berwenang memberikan peringatan pada Direksi yang merupakan juga sekaligus pemegang saham PT SJA untuk memberikan saran mengembalikan aset PT yang telah dibagikan berupa deviden kepada pemegang saham (Pasal 72 ayat (5) UUPT), jika terus diabaikan Dewan Komisaris dapat memberhentikan jabatan Direksi sementara (Pasal 106 ayat (1) UUPT)

20 Riska Fitriani. (2011). "Gugatan Derivatif Oleh Pemegang Saham Minoritas Pada Perseroan Terbatas”. Jurnal Ilmu Hukum. Volume 02, h. 182. 
dengan alasan karena telah melakukan kelalaian terhadap pembagian deviden yang mengakibatkan kerugian pada PT.

\section{Upaya Hukum Pemegang Saham Lain}

Pemegang saham dapat secara langsung melakukan upaya hukum menggugat Direksi atas nama PT karena terlibat pemanfaatan aset PT melalui forum RUPS pembagian deviden interim (Pasal 97 ayat (6) UUPT) atau yang dikenal dengan gugatan derivatif untuk menggugat Direksi untuk dan atas nama PT. ${ }^{21}$ Pemegang saham yang menggugat dapat kasus pengambilan deviden interim merupakan pemegang saham yang tidak setuju atas RUPS pembagian deviden, karena penentuan keputusan RUPS berdasarkan hak suara maka sudah tentu pemegang saham mayoritas memenangkan untuk agenda RUPS pembagian deviden tersebut. Pemegang saham mayoritas memiliki pengendalian yang besar atas hak suaranya dalam RUPS yang dapat dimanfaatkan untuk merugikan PT yang dilakukan melalui forum RUPS pembagian deviden interim. Upaya hukum yang dapat dilakukan lainnya oleh pemegang saham minoritas jika dirugikan dengan keputusan RUPS (Pasal 61 ayat (1) UUPT) untuk mengajukan gugatan langsung kepada PT akibat diperlakukan tidak adil oleh Direksi, Komisaris dan atau RUPS, ${ }^{22}$ gugatan langsung (direct suit) merupakan gugatan pribadi atas nama diri pemegang saham sendiri untuk menggugat PT akibat tindakan Direksi, Komisaris, dan RUPS, ${ }^{23}$ karena baik pemegang saham minoritas maupun pemegang saham mayoritas memiliki hak yang sama dalam menentukan kebijakan perusahaan melalui forum RUPS.

\section{Upaya Hukum Pemanfaatan Aset PT Melalui Rangkap Jabatan Sebagai Direksi}

Melalui jabatan sebagai Direksi Pemegang Saham memiliki peluang besar untuk menyalahgunakan kekayaan PT untuk keperluan pribadinya yang

\footnotetext{
${ }^{21}$ Adrian Sutedi, op.cit., h. 157.

22 Dian Indra Prabawati Dharma, dkk. (2013). "Upaya Perlindungan Hukum terhadap Pemegang Saham Minoritas Dalam Melindungi Kepentingannya”. Kertha Semaya. Volume 01, h. 5 .

${ }^{23}$ Maya Sari dkk. (2017). "Perlindungan Hukum Bagi Pemegang Saham Minoritas Yang Tidak Dilibatkan Dalam Proses Akuisisi”. Yuridika. Volume 22, h. 446.
}

dapat mengakibatkan PT mengalami kerugian akibat pemanfaatan aset tersebut. Kasus Putusan Pengadilan Negeri Denpasar Nomor 1013/Pib.B/2013/PN.Dps bahwa ADE selaku Direksi dan pemegang saham 50\% (lima puluh persen) dari PT Cylax telah memanfaatkan aset PT melalui jabatannya selaku Direksi dengan menjual aset PT berupa HGB No. 254/ Desa Pecatu An. PT. Cylax International, serta menggunakan hasil penjualan aset untuk keperluan pribadi dengan mentransfer hasil penjualan aset tersebut pada rekening pribadi direksi.

Dewan Komisaris selaku pemangku jabatan pengawan PT (Pasal 108 ayat 1 UUPT), seharusnya dapat mencegah terjadinya penyelewengan aset PT oleh Direksi, dalam kapasitas sebagai Direksi pemegang saham berpeluang menggukan aset PT untuk kepentingan pribadi, upaya hukum yang dapat dilakukan oleh komisaris untuk mencegah sementara penyelewengan aset PT tersebut dengan memberhentikan Direksi sementara untuk waktu 30 hari, sebelum dikuatkan oleh RUPS untuk perberhentian jabatan Direksi (Pasal 106 ayat (1) UUPT).

Upaya hukum yang dapat dilakukan pemegang saham dengan menggugat Direksi berdasarkan redaksi pasal UUPT pada Direksi karena telah mengakibatkan PT mengalami kerugian akibat pencampuradukan kepentingan antara kepentingan Direksi dengan kepentingan PT. Upaya hukum lain yang dapat dilakukan dengan memberhentikan jabatan Direksi melalui forum RUPS sebagai upaya menanggulangi tidak banyaknya kerugian atas tindakan Direksi tersebut.

\section{PENUTUP}

\section{Kesimpulan}

Terhadap penyalahgunaan aset PT oleh pemegang saham baik secara langsung maupun tidak langsung berdasarkan Pasal 3 ayat (2) huruf b UUPT seperti dicontohkan melalui forum RUPS, maupun di luar forum RUPS merupakan perbuatan melanggar hukum. Pemegang saham dapat dimintai pertanggungjawaban secara pribadi jika nantinya PT tidak dapat memenuhi kewajiban pada pihak ketiga.

Upaya Hukum yang dapat dilakukan terhadap pengembalian aset PT yang dapat digunakan yaitu: 1) Upaya hukum oleh pemegang saham lain (gugatan derivatif) untuk menggugat direksi jika Direksi 
terlibat atau membiarkan aset PT disalahgunakan untuk kepentingan pribadi, atas kerugian perseroan karena penyalahgunaan aset PT baik melalui RUPS, maupun melalui rangkap jabatan sebagai Direksi; 2) Direksi dapat melakukan upaya hukum dengan cara menggugat pemegang saham yang menyalahgunakan aset PT secara langsung.

\section{Rekomendasi}

Untuk memberikan perlindungan hukum kepada pihak ketiga yang berhubungan dengan PT, pemerintah seharusnya dapat melakukan pengawasan secara berkala terhadap organ-organ yang ada di balik PT, Pasal 138 ayat (3) UUPT memberikan hak pihak ketiga untuk mengajukan pemeriksaan terhadap PT, namun tidak dapat menggugat secara langsung organorgan di balik PT yang telah memanfaatkan aset PT untuk keperluan pribadi; serta Merekomendasikan kepada pemerintah melakukan pengawasan terhadap organ-organ PT terkait kepemilikan saham pada PT karena berpotensial terjadi penggunaan aset PT untuk kepentingan pribadi, mengenai kewajiban Direksi untuk melaporkan jumlah saham yang dimilikinya maupun saham yang dimiliki oleh keluarganya pada PT (Pasal 101 ayat (1) UUPT), dan kewajiban Dewan Komisaris untuk melaporkan jumlah saham yang dimilikinya maupun saham yang dimiliki oleh keluarganya pada PT (Pasal 116 huruf b UUPT), terhadap kewajiban tersebut tidak efektif dilakukan jika dalam PT semua pemegang saham adalah keluarga Direksi dan/atau Dewan Komisaris, karena untuk menggugat organ PT khususnya terkait penggunaan aset PT untuk kepentingan pribadi PT hanya pihak-pihak yang ada dalam organ PT tersebut yang dapat melakukan upaya hukum.

\section{DAFTAR PUSTAKA}

\section{Peraturan Perundang-undangan:}

Undang-Undang Nomor 40 Tahun 2007 tentang Perseroan Terbatas, Lembaran Negara Republik Indonesia Tahun 2007 Nomor 106, Tambahan Lembaran Negara Republik Indonesia Nomor 4756.

\section{Putusan Pengadilan:}

Putusan Pengadilan Negeri Surabaya Nomor 83/ Pdt.G/2016/PN.Sby.
Putusan Pengadilan Negeri Denpasar Nomor 1013/ Pib.B/2013/PN.Dps.

\section{Buku:}

Abdulkadir Muhammad. (2010). Hukum Perusahaan Indonesia. Cetakan ke IV. Bandung: Citra Adhitya Bakti.

Adrian Sutedi. (2015). Buku Pintar Hukum Perseroan Terbatas. Jakarta: Raih Asa Sukses.

Azizah. (2016). Hukum Perseroan Terbatas. Malang: Setara Press.

Bonifasius Aji Kuswiratmo. (2016). Keuntungan \& Resiko menjadi Direktur, Komisaris dan Pemegang Saham. Cetakan Pertama. Jakarta: Visimedia.

M. Yahya Harahap. (2015). Hukum Perseroan Terbatas. Cetakan Kelima. Jakarta: Sinar Grafika. Munir Fuady. (2005). Perlindungan Pemegang Saham Minoritas. Cetakan Pertama. Bandung: CV Utomo.

. (2008). Hukum Perusahaan Dalam Paradigma Hukum Bisnis. Cetakan Ke III. Jakarta: Citra Aditya Bakti.

. (2014). Doktrin-Doktrin Modern Dalam Corporate Law dan Eksistensinya dalam Hukum Indonesia. Cetakan Ke III. Jakarta: Citra Aditya Bakti.

Ontarinton Purba. (2012). Petunjuk Praktis Bagi RUPS, Komisaris dan Direksi Perseroan Terbatas Agar Terhindar Dari Jerat Hukum. Cetakan Ke II. Jakarta: Raih Asa Sukses.

Peter Mahmud Marzuki. (2009). Penelitian Hukum. Cetakan ke 5. Jakarta: Kencana Premada Media Group.

R. Soemita dkk. (1980). Dasar-Dasar Akutansi I. Bandung: Tarsito.

Rudhi Prasetya. (2014). Teori dan Praktik Perseroan Terbatas. Jakarta: Sinar Grafika.

\section{Jurnal:}

Dian Indra Prabawati Dharma, dkk. (2013). "Upaya Perlindungan Hukum Terhadap Pemegang Saham Minoritas Dalam Melindungi Kepentingannya". Kertha Semaya. Volume 01 Nomor 11 November. Erman Rajagukguk. (2013). "Pengelolaan Perusahaan Yang Baik: Tanggung Jawab Pemegang Saham, Komisaris dan Direksi”. Lex Yuridika. Volume 26 Nomor 3 November. 
Kurniawan. (2014). "Tanggung Jawab Pemegang Saham Perseroan Terbatas Menurut Hukum Positif”. Jurnal Mimbar Hukum. Volume 01 Nomor 1 Juni.

Maya Sari dkk. (2017). "Perlindungan Hukum Bagi Pemegang Saham Minoritas Yang Tidak Dilibatkan Dalam Proses Akuisisi". Yuridika. Volume 32 Nomor 3 September.
Riska Fitriani. (2011). "Gugatan Derivatif oleh Pemegang Saham Minoritas Pada Perseroan Terbatas". Jurnal Ilmu Hukum. Volume 02 Nomor 01 Februari.

Try Widiono. (2013). "Perkembangan Teori Hukum dan Doktrin Hukum Piercing The Corporate Viel dalam UUPT dan Realitanya Secara Prospektif Kedepannya". Lex Juridica. Volume 10 Nomor 1 April. 